\title{
A Study on the Phenomenon of Overeducation in China and Its Trend Analysis
}

\author{
Mengshu Lu \\ Institute of Economics, Jinan University, Guangzhou, China \\ Email: 543366037@qq.com
}

How to cite this paper: Lu, M.S. (2017) A Study on the Phenomenon of Overeducation in China and Its Trend Analysis. Open Journal of Social Sciences, 5, 191-204. http://dx.doi.org/10.4236/jss.2017.51015

Received: December 29, 2016

Accepted: January 17, 2017

Published: January 20, 2017

Copyright $\odot 2017$ by author and Scientific Research Publishing Inc. This work is licensed under the Creative Commons Attribution International License (CC BY 4.0).

http://creativecommons.org/licenses/by/4.0/

\section{(c) (i) Open Access}

\begin{abstract}
The paper analyzes the overeducation incidence in different department and occupation by mode method. Our conclusions are, first, overeducation occurrence is relatively high mainly among senior skilled workers since the quality requirement of the professors and doctors is much higher in China, and, second, the incidence of overeducation in husbandry remains at a low level all the way which indicates that the agricultural human capital attraction and level is weak due to the inferior income. Based on the ORU model, we found that the yield of education changes along with the economic development of China by analyzing the yield of overeducation from 1997 to 2011. The yield of overeducation gradually increased from 1997 to 2011 but it fell after the economic crisis then rose up again in low velocity with the return of every job differing. The income of the senior over educated technical workers is higher than the unskilled ones. People's income disparity is expanding between the workers receiving more and less education over time.
\end{abstract}

\section{Keywords}

Overeducation, The Incidence Rate of Overeducation, Human Capital, The Return of Overeducation, Trend Analysis, Income Disparity

\section{Introduction}

The economic development needs the support of human capital. W. Schultz Theodore (1963) indicates that the human capital is a significant source of the economic growth in the book, Economic Value of Education. Chinese leaders put forward the strategy of revitalizing the country through science and technology in 1995, emphasizing that the development of China cannot do without science, technology and education. Not only in China, the rapid economic development in Japan and Germany's after the world war two also demonstrates 
that the accumulation of human capital is inevitable for economics. Under the era of knowledge-based economy, specifically, education is playing a more and more important role in economic development to a single nation. Therefore, in 1999, China enlarged the scale of enrollment of higher education by increasing the availability of the enrollment.

As seen in Figure 1, the golden age of the higher education development has arrived since 1998. Scale of admitting increased from 1.08 million to 6.75 million, which increase over 6 times, from 1998 to 2011. According to the National Education Development Statistics Bulletin, after a few years of development of higher education, the number of higher education has reached 21.45 million and the enrollment rate of higher education has reached $72 \%$ in China comparing with $36 \%$ in 1997. Mass education is gradually taking the place of the elite education in China.

As seen in Figure 2, it increases from 0.24 million to 1.51 million from 1997 to 2011. The growth rate of the enrollment of postgraduate education in China is also rapidly expanding. It increases from 0.24 million to 1.51 million from 1997 to 2011. The growth rate of the enrollment increases over 6 times indicating that residents' educational awareness is gradually enhancing. Meanwhile, China is raising the admitting number of postgraduate education enrollment which increases over 9 times from 0.051 million in 1997 to 0.495 million in 2011. The increasing multiple of candidates admitted is larger than that of the registration shows that the national policies make it easier for students to get access to the higher education.

Because of the expansion of enrollment scale, the educational attainment situation in China is improving. The promotion of national educational attainment develops Chinese cultural power and people's quality. At the same time, domestic demand is boosted relying on the development of education. Moreover, the increment of people in school and the decrease of current graduation quantity will alleviate parts of the employment problems.

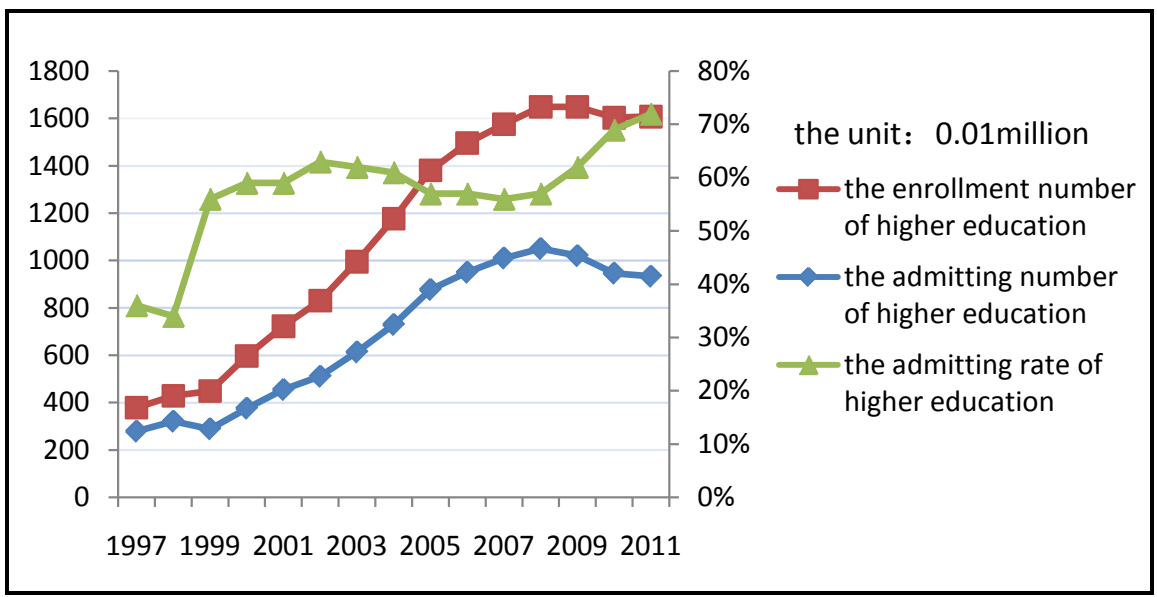

Figure 1. Number of college entrance examination and admission from 1997 to 2011 in china. Data source: "new China statistical data compilation of sixty years" and "China statistical annual inspection" in 2012. 


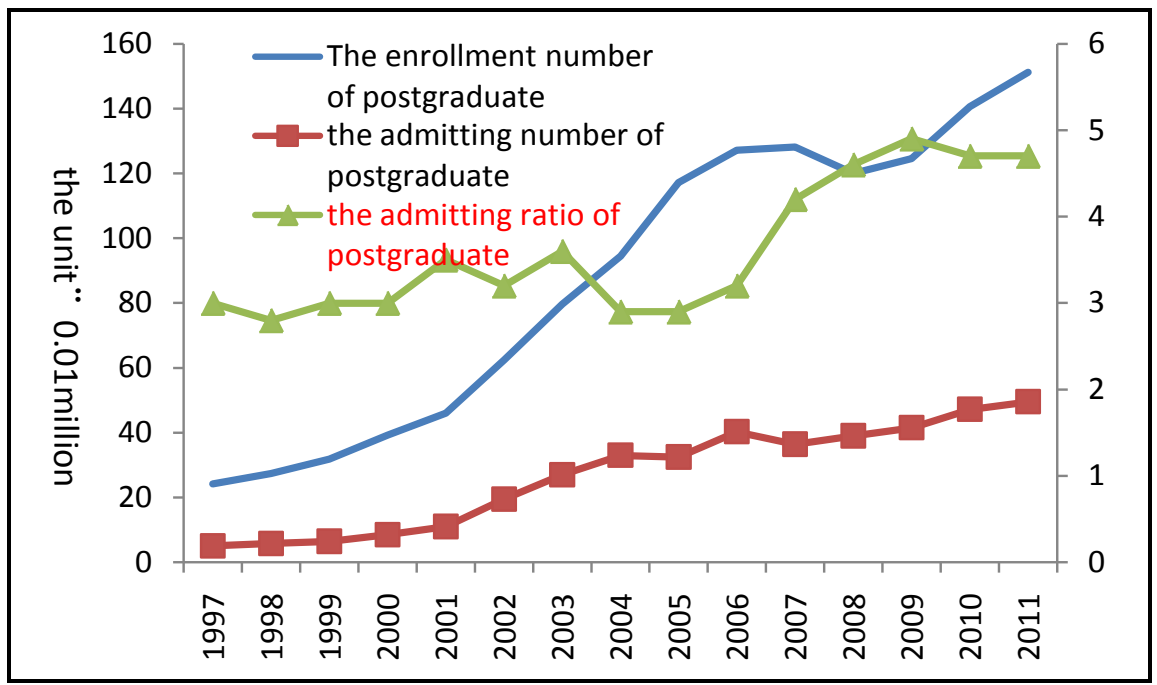

Figure 2. Number of registration and enrollment of postgraduate from 1997 to 2011 in China. Data source: "new China statistical data compilation of sixty years" and "China statistical annual inspection" in 2012.

However, the expansion of Chinese education may lead to an imbalance between supply and demand of the labor market. Although the current employment figure is reduced by enlarge the scale of postgraduate education, the supply of the market is still beyond the demand. For instance, the labor-intensive enterprises, which require little educated labors, are still occupying the majority in Chinese industrial construction. If the development of high-tech industry in China cannot keep up with the pace of the graduates, the disequilibrium of the supply-demand of the labor market would still occur. In this context, the situation of overeducation and the allocation of labor market in China need to be probed and the solution to how to raise the allocation efficiency of the talent labors is urgently needed.

This article first introduced the research background and significance. Then it mainly introduces the related theory of excessive education and the research at home and abroad. At last, it proposed research methods and research ideas. Education plays an important role on development of our country in the development. To understand the present situation of the country's education, it can be targeted to solve obstacle in the education.

\section{Overseas and Domestic Research Status}

The phenomenon of overeducation initially happened in foreign countries. The concept of overeducation is firstly put forward by Freeman (1976) in his study about the supply-demand condition within the U.S. labor markets of the graduate students. Thereafter, large amounts of research on the measurement and the yield of the overeducation have done by the foreign scholars. Carrolla and Massimiliano Tani (2013) found that there are (were) $24 \%$ and $37 \%$ of Australian grad students suffered in overeducation who are (were) mostly young female and the phenomenon of overeducation fades over time [1]. Lindley Joanne 
(2009) has done her research on particular groups of people in terms of their different social traits. By analyzing the statistics of the England migration and other ethnic minority, the results differ. Comparing to the white people, black people, Indians and the non-black people are more tend to be over educated and the Indian, Pakistan and Bangladesh women also share greater possibilities on overeducation as well. But greater chances of finding a job in UK lie in those over-educated groups [2]. Frenette (2004) uses the datasets from Canadian National Graduate Survey (NGS) and a fixed effect model to analyze the probability, sustaining rates and the yield of overeducation of the Canadian graduates. Base on the study, the overeducation rate differs among different educational levels and majors while the postgraduate students share greater tendency on overeducation over the undergraduate students. And the study also found there is negative correlation between wage and overeducation in the labor market [3]. Dearden (1998) imply the OLS method to estimate the influence of education on the income. It indicates that the deviation caused by the unobservable intrinsic ability and family background can be neutralized by measuring the bias and the self-selection bias. The traditional OLS estimation is effective under this circumstance [4] Blundell (2001) implies two different estimation methods (matching method, least squares method) to estimate the individual's educational yield controlling the individuals' abilities and background differences finding that the results of the two groups are close [5]. Dearden's test about OLS estimation is testified to be effective [4]. Lindley and Steven McIntosh Joanne (2008) testify that the occurrence of overeducation develops over time [6]. It rises first then goes downward. According to one of the studies done by the International labor Organization (ILO), the incidence of overeducation is rising during the period of 2002-2010 in most countries while there was a downward tendency in Eastern Europe.

Sheng Shiming (2004) summarizes the definitions and the measure methods of overeducation in foreign countries and comparisons and analysis has been done on the incidence rate of overeducation and the research methods of the rate of return as well [7]. Luo Rundong and Peng Mingming (2010) utilizing the datasets from Chinese social survey to analyze the impact of the mismatch of Chinese education on people's revenue [8]. They look into the situation of education in different industries illustrating that overeducation occurrence maximum in the areas such as power generating and water supply industry, manufacturing and mining industry. The lack of education is relatively low within sports department, sanitation department and social welfare department. Zhang Xiaobei and Yuan Peng (2010) obtain data from the national comprehensive social survey and imply overeducation income model to examine some theories (Work Competition Theory, Distribution Theory and Human capital Theory) about overeducation [9]. Concluding that despite the existence of overeducation, our country still bases on appropriate education. Overeducation not only impedes the labor wage promotion, but also influences the individual productivity indirectly which will ultimately lead to a lower production efficiency. Miu Yu- 
huan (2013) establishes an ordinal regression model and non-parametric test to analyze the status of China's overeducation and its influence factors exploring the gap between educational level of the companies' requisition and the employee's level [10]. The study finds that worker's education is mainly influenced by the company ownership, scale, family size and other factors. Overeducation is a temporary phenomenon for individuals (Oliveiraa), but it is a long-term phenomenon for the whole society. Overeducation affects the degree of workers' satisfaction then the production efficiency. It brings a huge challenge for the economy and industrial transformation (Belfield Tsang Mun [11] [12], Chiu Clive). Yang Juan (2008) reviews the measurement of the educational yield in overseas and domestic studies and evaluates their advantages and disadvantages through introducing several educational returns (instrumental variable method, fixed effect method, least square method, matching method). The traditional OLS is found to be relatively more reliable and easier to operate than other commonly used estimation methods.

Most of these studies are summing up and testifying the conclusions of the theory of overeducation in foreign countries. On this basis, I establish the mode model and the ORU model to study the phenomenon of overeducation and the relationship between the Gross Domestic Product and the yield of Education in China.

\section{Theoretical Basis of Overeducation}

Overeducation means the expansion of higher education from the macro perspective which causes the supply of labors receiving higher education over the number of the available jobs. The interpretation of overeducation was firstly given by the human capital theory. In a perfect competition labor markets, the supply and demand of workers will remain equilibrium under the wage mechanism. But the balance will be broken once the supply starts to increase, the wages will drop which makes it possible for the companies to recruit at a lower wage. For this reason, the individuals will also adjust their education level according to the lower wages and the supply and demand retain the equilibrium again in the long-run [13]. But the market actually doesn't work this way. There are three main theories about overeducation.

First, Alba-Ramirez (1993) and Alba-Ramirez, A. (1993) infers that the market information is asymmetric and the asymmetry between employers and employees may lead to the short supply of some specific occupations while the others are on the opposite. Overeducation happens when the employee's educational level is higher than the job requires. Them is match is commonly seen within the newly graduates. With the accumulation of working experiences, employees will be able to obtain a competent job [14].

There is a second explanation considering overeducation as a short term phenomenon because the education experience and work experience are substitution for one another other. There will be employees with low educational level but ample working experience and some highly educated ones but with less 
experience [15]. But the highly educated ones will be promoted to the position that fits their ability with the increasing of working experience in a short period. The phenomenon of overeducation will be excluded in the long time by such mechanism. There are other theoretical explanations for the overeducation.

Thurow (1979) poses that there are two ideal queues among the enterprises and the job seekers, the job queue and the person queue. Enterprises rank the job seekers by their educational level, work experiences and the technic that they master in order to choose the best candidates at the lowest cost. In the whole process of the candidates screening, the enterprises will increase or decrease the available jobs base on the economic situation so the individuals need to raise the probability of being picked by investing in education [16] [17].

There are also other theoretical interpretations for the overeducation, such as screening theory, distribution theory, market segmentation theory, space flow theory, etc. Screening theory believes that employers mainly base on the degree to select their employees due to the asymmetry of information. Distribution theory attributes the reason of overeducation to the low efficiency caused by the misallocation of labors' features. The space flow theory considers that the information asymmetry between supply and demand leads to a wasting of resources. Market segmentation theory emphasize that the high cost produced in the process of human capital flowing from one market to another should be blamed for overeducation. And overeducation tends to occur in areas with weak liquidity.

In this paper, the overeducation yield model is based on human capital theory. The most obvious advantage of ORU is that it can reflect the supply and demand in labor market simultaneously. The revenue of labors is determined by the supply and demand of human capital. But the ORU model splits the one and only human capital which measured by individual educational level into three parts as the job requirement of educational level, the over-education period and the under-education period.

\section{Data and Sample Description}

To address our research, we utilize the datasets provided by the China Health and Nutrition Survey (CHNS) from 1997 to 2011. We chose individual wages table, the education situation table and the working situation table from the survey. The sample sizes in those three tables are different. In order to merge the observations into one complete table, we've done a few data reduction processes. Each observation is identified by three variables together, the individual number, family number and year. We drop the observations with negative wage and missing variables. Then we restrain the observations down to 8 provinces which can cover the overall situation on the whole containing Liaoning, Jiangsu, Henan, Hubei, Hunan, Guizhou, Heilongjiang and Guangxi. The work experiences are not directly provided by the data, but we estimate the working experience equals age-education years-6 and the observations with negative value are dropped so that we can assure all the observations are actual workers. The age of 
the sample is between 16 and 55 years old. Wage is deflated to real wage to eliminate the impact of inflation. We choose 1997 as the benchmark year. The consumer index of 1997 is 100 .

Table 1 is a statistical description of the selected sample. The table shows that the individual's wages gradually increased from 376.8 yuan to 1959 yuan from 1997 to 2011 which increase approximately 4 times. The average individual education years rose from 9.21 to 11.25 from 1997 to 2011 . That is to say, the highest educational level of the individuals improved from junior high to senior high. In 1997, most families merely let their children go through the nine years compulsory education. But with the rising of employment pressure and the improvement of living standards, a majority of parents encourage their children to get higher degree after graduating from secondary schools realizing that education is increasingly significant.

From Table 2, the statistic reveals that the proportion of whose highest degree is primary and high school is gradually reducing. People who failed in admitting to the University will choose to go to the technical school proportionately. This option has become the mainstream since 2004. And the proportion of people

Table 1. Statistical description of the sample.

\begin{tabular}{|c|c|c|c|c|c|c|c|}
\hline variable & unit & 1997 & 2000 & 2004 & 2006 & 2009 & 2011 \\
\hline & & $\begin{array}{c}\text { Mean standard } \\
\text { deviation }\end{array}$ & $\begin{array}{c}\text { Mean standard } \\
\text { deviation }\end{array}$ & $\begin{array}{c}\text { Mean standard } \\
\text { deviation }\end{array}$ & $\begin{array}{c}\text { Mean standard } \\
\text { deviation }\end{array}$ & $\begin{array}{c}\text { Mean standard } \\
\text { deviation }\end{array}$ & $\begin{array}{c}\text { Mean standard } \\
\text { deviation }\end{array}$ \\
\hline \multirow[t]{2}{*}{ Education years } & years & 9.210 & 9.610 & 10.55 & 10.68 & 10.46 & 11.25 \\
\hline & & $(3.080)$ & $(3.041)$ & $(2.958)$ & $(3.189)$ & $(3.177)$ & $(3.274)$ \\
\hline \multirow[t]{2}{*}{ Working years } & years & 20.11 & 20.36 & 21.88 & 22.70 & 23.21 & 22.32 \\
\hline & & $(10.84)$ & $(10.88)$ & $(10.15)$ & $(10.21)$ & $(10.09)$ & $(10.08)$ \\
\hline \multirow[t]{2}{*}{ Monthly salary } & yuan & 376.8 & 422.4 & 668.5 & 917.0 & 1513.3 & 1959.2 \\
\hline & & $(441.4)$ & $(816.4)$ & $(1737.9)$ & $(2202.9)$ & $(3326.0)$ & $(3545.3)$ \\
\hline Llogarithm of & & 5.946 & 6.229 & 6.587 & 6.785 & 7.183 & 7.560 \\
\hline monthly wages & & $(0.565)$ & $(0.605)$ & $(0.583)$ & $(0.624)$ & $(0.646)$ & $(0.631)$ \\
\hline $\mathrm{N}$ & & 2609 & 2696 & 1933 & 2064 & 2344 & 3548 \\
\hline
\end{tabular}

Data source: China health and nutrition survey.

Table 2. The proportion of education in the sample, unit: $\%$.

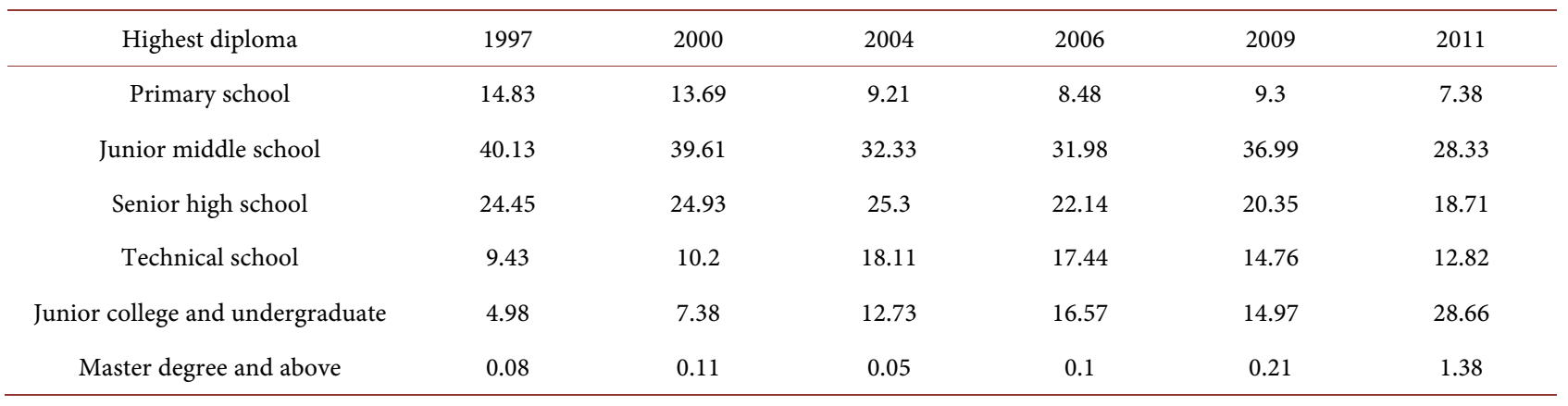

Data source: China health and nutrition survey. 
with university education or above is soaring. The proportion of people with college or bachelor degree increases from $4.98 \%$ to $28.66 \%$ around 1997 to 2011 , which gains over 5times. But the growth of postgraduate is even more reaching over 17 times. Given that the base of postgraduate is small explain that the more significant growth rate. In general, the solid raise of the proportion of the bachelor or above degree and the faster pace of the higher education than the wage partly reflect the suitable occupation availability cannot perfectly match the growth of the educational level.

\section{Results and Discussion}

Hartog \& Tsangyaa (2009) apply WA to find out the education level that a specific job using the workers' self-assessment method. The study was carried out mainly through the questionnaire consulting the workers about the questions which is a relatively subjective method.

There is another method but also blamed to be subjective called JA. The results are provided by the professional evaluators therefore the results are relatively consistent. For example, Dictionary of the Occupational Titles (DOT) in United States lists the technics and abilities that different jobs require like a job encyclopaedia.

In fact, the actual matching method (RM) [18], a quantitative method which was firstly presented in a paper of Verdugo in 1989 studying the influence of income, is most widely used to determine the competent education level for a job by most researchers. Mean value method is the key of RM measuring the jobs' requiring education level. Kiter adjusted the method by replacing the mean value method by mode method during studying the yield of overeducation and under education.

Comparing with other methods, JA is the most precise one due to its consistent results and is recommended for studying overeducation. But there are a few defects about it. The examining scale is so large that the cost is exorbitant and the timeliness is too weak to reflect the current situation. WA reflects the current situation well but it's not accurate enough because everyone's feeling is too subjective to reveal the reality. Since there is no existing reliable JA in China and WA is not valid enough, we chose the mode method of RM to study the requiring education level of the jobs and to estimate the incidence of overeducation by mode method.

Measuring by time, senior technical workers (doctor, professor and lawyer, etc.) are perpetuating the biggest group of overeducation and the unskilled workers are smaller than senior or junior technical workers while the peasants are the smallest. The development of China needs the support of those senior technical workers such as lawyers, architects and engineering which absorbing a lot of overeducation labors. On the contrary, peasants and unskilled workers need little human capital due to the low technology of the jobs (see Table 3).

From the social sectors' ankle, government departments share the greatest proportion of the overeducation group explained by the popularity of public 
official occupations of the society. The overeducation rate within enterprises supported by foreign capital such as WFOEs, overseas-Chinese funded enterprises and joint ventures reached the peak in 2006 and, despite it falls later on, is still over the amount in SOEs and collective enterprises. The attribution of this phenomenon should lie in the great attraction of the newly developed foreign enterprises. The SOEs we've mentioned about are going through a draining of overeducation workers probably due to the SOE reform which leads to a decreasing standard of working in the SOEs. However, on the whole, the overeducation rates of the enterprises or departments mentioned above are relatively high except the collective enterprises. These overeducation workers share a tendency of hunting a job in developed cities. In order to promote the development of the smaller cities or towns, authorities should carry out some incentive policies to distribute parts of the human capital to exploit these less developed areas (see Table 4).

\subsection{To Estimate the Yield of Overeducation by ORU}

The Mincer (1989) [19] revenue function

Table 3. Incidence of overeducation in different positions from 1997 to 2011.

\begin{tabular}{ccccccc}
\hline & 1997 & 2000 & 2004 & 2006 & 2009 & 2011 \\
\hline farmer & $11.27 \%$ & $10.51 \%$ & $16.30 \%$ & $18.10 \%$ & $12.05 \%$ & $17.65 \%$ \\
Senior technicians & $45.99 \%$ & $43.83 \%$ & $35.48 \%$ & $44.92 \%$ & $54.04 \%$ & $64.37 \%$ \\
Generaltechnicians & $30.48 \%$ & $47.62 \%$ & $26.92 \%$ & $45.05 \%$ & $42.47 \%$ & $50.32 \%$ \\
Skill mechanic & $33.73 \%$ & $40.56 \%$ & $49.42 \%$ & $47.60 \%$ & $36.95 \%$ & $43.02 \%$ \\
Unskilled mechanic & $20.28 \%$ & $22.60 \%$ & $27.85 \%$ & $26.15 \%$ & $24.34 \%$ & $30.16 \%$ \\
Manager & $55.64 \%$ & $67.97 \%$ & $30.23 \%$ & $37.57 \%$ & $36.07 \%$ & $45.92 \%$ \\
Service trade & $26.43 \%$ & $29.78 \%$ & $39.49 \%$ & $41.78 \%$ & $34.45 \%$ & $44.39 \%$ \\
Other & $35.16 \%$ & $16.53 \%$ & $28.37 \%$ & $37.80 \%$ & $31.73 \%$ & $40.50 \%$ \\
\hline
\end{tabular}

Data source: China health and nutrition survey.

Table 4. The incidence rate of overeducation of different Enterprise ownership from 1997 to 2011.

\begin{tabular}{ccccccc}
\hline & 1997 & 2000 & 2004 & 2006 & 2009 & 2011 \\
\hline The government & $58.38 \%$ & $43.89 \%$ & $34.97 \%$ & $41.67 \%$ & $42.57 \%$ & $44.26 \%$ \\
State owned enterprise & $21.90 \%$ & $33.71 \%$ & $29.10 \%$ & $39.05 \%$ & $40.66 \%$ & $49.16 \%$ \\
State-owned enterprise & $36.33 \%$ & $40.96 \%$ & $15.19 \%$ & $21.21 \%$ & $15.26 \%$ & $29.32 \%$ \\
Small collective & $13.13 \%$ & $8.93 \%$ & $43.85 \%$ & $43.38 \%$ & $47.87 \%$ & $11.92 \%$ \\
Big collective & $24.94 \%$ & $26.93 \%$ & $48.91 \%$ & $56.41 \%$ & $10.11 \%$ & $15.38 \%$ \\
Household contract & $37.21 \%$ & $31.94 \%$ & $14.94 \%$ & $18.35 \%$ & $13.73 \%$ & $15.57 \%$ \\
Individual & $36.36 \%$ & $21.33 \%$ & $35.71 \%$ & $35.82 \%$ & $32.42 \%$ & $42.21 \%$ \\
Joint ventures & & & & $62.07 \%$ & $46.48 \%$ & $36.75 \%$ \\
Other & $16.67 \%$ & $27.59 \%$ & $42.19 \%$ & $17.33 \%$ & $50.00 \%$ & $21.19 \%$ \\
\hline
\end{tabular}

Data source: China health and nutrition survey. 


$$
\ln w=a+\beta_{r} s+e x+\beta_{4} e x^{2}+\mu
$$

In the equation, $S$ denotes the individual education years. According to the human capital theory, the income will increase with the increasing working experience. In this equation, the working experience is taken into account besides the education level. But there are other decisive external factors of the income such as areas differences, ability differences and genders, etc.

Duncan, G. \& Hoffman, S. (1981) established an ORU model dividing the education years into three categories as overeducation, appropriate education and under education. Each category of education is measured by the job's need.

The model is as follow.

$$
\ln w=a+\beta_{1} x+\beta_{r} s_{r}+\beta_{o} s_{o}+\beta_{u} s_{u}+\beta_{3} e x+\beta_{4} e x^{2}+\mu
$$

Vectors $S_{0}, S_{\mu}$ and $S_{t}$ are measured by different equation according to different situation. When $S_{r}>S$. When $S_{r}<S, S_{\mu}=S_{r}-S_{\mu}$. and when $S_{r}=S$.

The vector $\mathrm{w}$ denotes the individual income. $\beta_{o}$ measures the change in the income when the education years increase a single unit comparing with the appropriate years which is commonly a positive value. $\beta_{u}$ measures the change in income when the education years is one less unit than the appropriate years. $\beta_{r}$ is the yield of appropriate education years. The vector ex in the equation denotes the working years of an individual. Vector $\mathrm{ex}^{2}$ denotes the square of the education years. $\mu$ is the residual and vector $\mathrm{X}$ denotes a set of controlling variables. The controlling variables we've chosen are areas difference, occupation types, ownership of the enterprises, genders, rural-urban differences and so on.

We use rural registrations of different individuals as the measurement of areas difference. And we use female as the base for genders. We divide the areas into eastern (including Jiangsu, Shandong, Liaoning), middle (including Henan, $\mathrm{Hu}$ bei, Hunan, Heilongjiang) and western (including Guizhou, Chongqing) parts and the western part is the base. And the ownership of the enterprises is divided into official department, collective enterprises, foreign-owned or private-owned enterprises and others and the official department is the base. For the occupation types, we categorize them into 9 types, senior technological workers (doctors, professors, engineers, etc.), common professional workers (nurses, midwives, teachers, etc.), administrators (executives or managers), common office workers (secretaries or office clerks), agriculture peasants, skilled workers, unskilled workers, service staffs and others.

\subsection{The Empirical Regression Analysis}

Following the ORU model and utilizing the samples from 1997 to 2011 of CHNS to carry out a dynamic analysis about overeducation. The datasets are cross- sectional in this paper. We estimate the yield of overeducation by years. The controlling variables such as areas, occupations, ownership of the enterprises are all dummy variables. Here is the result of the regression.

Secondly, the yield of overeducation is positively related to the education years while the relation of under education is negative. Income premium can be 
gained by additional education when the yield of overeducation is smaller than the appropriate education. But the utility of human capital surplus in China haven't been maximized.

The yield disparity between overeducation and appropriate education has been narrowing since 1997 when the yield of appropriate education is declining while the situation of overeducation is on the opposite. The yield of overeducation was about 5 times less than that of the appropriate education before 2004 . But after 2006, the gap narrowed down to approximately none and keeps on narrowing from $18.8 \%$ in 1997 to $1 \%$ in 2011 . The attention to higher education and talents has been paid by the society. The revenue gap between over and appropriate education is gradually widening. Moreover, the impact on income of the overeducation is turning to be stronger while the appropriate education turns to be weaker. All these changes are elaborating one problem that the application of human capital in China is more and more efficient (see Table 5).

Table 5. The dynamic analysis of yield of overeducation on sample.

\begin{tabular}{|c|c|c|c|c|c|c|}
\hline & 1997 & 2000 & 2004 & 2006 & 2009 & 2011 \\
\hline Intercept & $3.265^{* * *}$ & $3.966^{* * *}$ & $4.653^{* * *}$ & $5.255^{* * *}$ & $5.846^{* * *}$ & $6.165^{\star * *}$ \\
\hline Overeducation & $0.023^{\star * *}$ & $0.020^{\star *}$ & $0.032^{\star * *}$ & $0.073^{\star * *}$ & $0.053^{\star * *}$ & $0.060^{* * *}$ \\
\hline Appropriate education & $0.192^{\star * *}$ & $0.157^{\star * *}$ & $0.148^{\star * *}$ & $0.088^{\star * *}$ & $0.054^{* *}$ & $0.069^{* * *}$ \\
\hline Education shortage & -0.008 & -0.001 & $-0.042^{\star \star \star}$ & $-0.020^{\star \star}$ & $-0.024^{\star \star \star}$ & $-0.025^{\star * *}$ \\
\hline Working experience & $0.021^{* * *}$ & $0.020^{* * *}$ & $0.018^{\star * *}$ & $0.020^{* * *}$ & $0.018^{* * *}$ & $0.016^{* * *}$ \\
\hline Empirical square & $-0.000^{\star * *}$ & $-0.000^{* * *}$ & $-0.000^{\star * \star}$ & $-0.000^{\star * \star}$ & $-0.000^{\star \star \star}$ & $-0.000^{* * *}$ \\
\hline \multicolumn{7}{|c|}{ Take government units as the reference group } \\
\hline Collective economy & $0.470^{* * *}$ & $0.211^{* * *}$ & $-0.165^{\star * \star}$ & $-0.206^{\star * *}$ & $-0.128^{\star * *}$ & $-0.138^{* * *}$ \\
\hline Individual joint ventures & $0.148^{\star *}$ & -0.077 & $0.063^{*}$ & $0.097^{\star * *}$ & $0.057^{\star}$ & $0.095^{\star * *}$ \\
\hline Other & $0.519^{\star * *}$ & 0.153 & $-0.210^{\star * \star}$ & -0.050 & $-0.230^{\star \star \star}$ & -0.064 \\
\hline Administrative office & -0.033 & 0.014 & $-0.164^{\star * *}$ & -0.084 & $0.141^{\star *}$ & 0.067 \\
\hline Senior technicians & -0.002 & $0.300^{* * *}$ & 0.000 & $0.129^{* *}$ & $0.328^{* * *}$ & $0.249^{* * *}$ \\
\hline General technicians & 0.000 & $0.322^{* * *}$ & $-0.122^{\star *}$ & 0.000 & $0.256^{* * *}$ & $0.165^{\star * *}$ \\
\hline Skilled mechanic & $0.379^{* * *}$ & $0.393^{* * *}$ & 0.061 & 0.019 & 0.049 & $0.150^{\star *}$ \\
\hline Unskilled mechanic s & $0.250^{* * *}$ & $0.348^{\star * *}$ & -0.080 & $-0.118^{*}$ & -0.042 & -0.007 \\
\hline Administration & $0.261^{\star * *}$ & $0.502^{\star * *}$ & $-0.187^{\star \star *}$ & 0.000 & $0.142^{\star *}$ & $0.117^{\star \star}$ \\
\hline Service trade & $0.391^{* * *}$ & $0.392^{\star * *}$ & 0.068 & $-0.129^{*}$ & -0.074 & -0.069 \\
\hline Other & $0.400^{* * *}$ & 0.000 & 0.139 & $-0.136^{*}$ & 0.000 & 0.000 \\
\hline \multicolumn{7}{|c|}{ Take women as the reference object } \\
\hline Male & $0.200^{\star * *}$ & $0.227^{\star \star *}$ & $0.172^{\star * *}$ & $0.248^{\star * *}$ & $0.332^{\star \star *}$ & $0.237^{\star * *}$ \\
\hline \multicolumn{7}{|c|}{ Taking the rural areas as the reference object } \\
\hline \multicolumn{7}{|c|}{ Taking the western region as the reference object } \\
\hline Eastern area & $0.221^{\star * *}$ & $0.144^{* * *}$ & $0.197^{\star * *}$ & $0.207^{\star * *}$ & $0.136^{* * *}$ & -0.030 \\
\hline Middle area & $0.111^{\star * *}$ & -0.025 & 0.044 & $0.108^{\star * *}$ & $0.122^{\star * \star}$ & $-0.093^{\star * *}$ \\
\hline$N$ & 2473 & 2353 & 1894 & 2022 & 2298 & 3411 \\
\hline$R^{2}$ & 0.155 & 0.117 & 0.190 & 0.209 & 0.218 & 0.200 \\
\hline
\end{tabular}

Standard errors in parentheses ${ }^{*} \mathrm{p}<0.10,{ }^{* *} \mathrm{p}<0.05,{ }^{* * *} \mathrm{p}<0.01$. Data source: China health and nutrition survey. 
According to this tendency, education factor is conquering the whole label market which means the pursuit of higher education and higher income will be fiercer.

For more, there is great consistency that the yield of overeducation fluctuating along with the economics fluctuation. After comparing the changing rates of the overeducation yield with the GDP, high overeducation rate is noticed during economic boom time and low during recession (see Figure 3). For instance, the yield of overeducation rose from $2.3 \%$ to $7.3 \%$ during 1997 to 2006 and then dropped to $5.3 \%$ in 2009 which the economic development presented the same moving trend. In China, in a long period after joining the WTO in 2000 and enrollment expansion in 1999, Chinese economics took off thanks to the international cooperation and abundant human capital supplement. The real GDP growth reached $12.7 \%$ and $14.2 \%$ in 2006 and 2007. The economic development needs the guarantee of human capital supply which stimulates the overeducation spontaneously.

During the economic crisis in 2008, the export market stuck and the commercial profits plunged which leads to the extraction and lay off of enterprises. Therefore, a large amount of graduates remained unemployed and the yield of overeducation also dropped about $2 \%$ to $5.3 \%$ in 2009 . Although 4 trillion yuan was invested in the society to stimulate the economic recovery in 2011, there was no significant change of the overeducation yield because the demand of labors remained weak. There was another period that the yield of overeducation and GDP without great changes. During 1997 to 2000, China was recovering from the Asian financial crisis and the enrollment expansion policy was carried out in 1999 which hasn't functioned yet. So the overeducation yield didn't change much. In 2006, the overeducation yield reached 7.3\% along with the growth rates of the GDP reached $8.7 \%$. The utilizing of the human capital was efficient. Education and economics flourish mutually supported the development of one another.

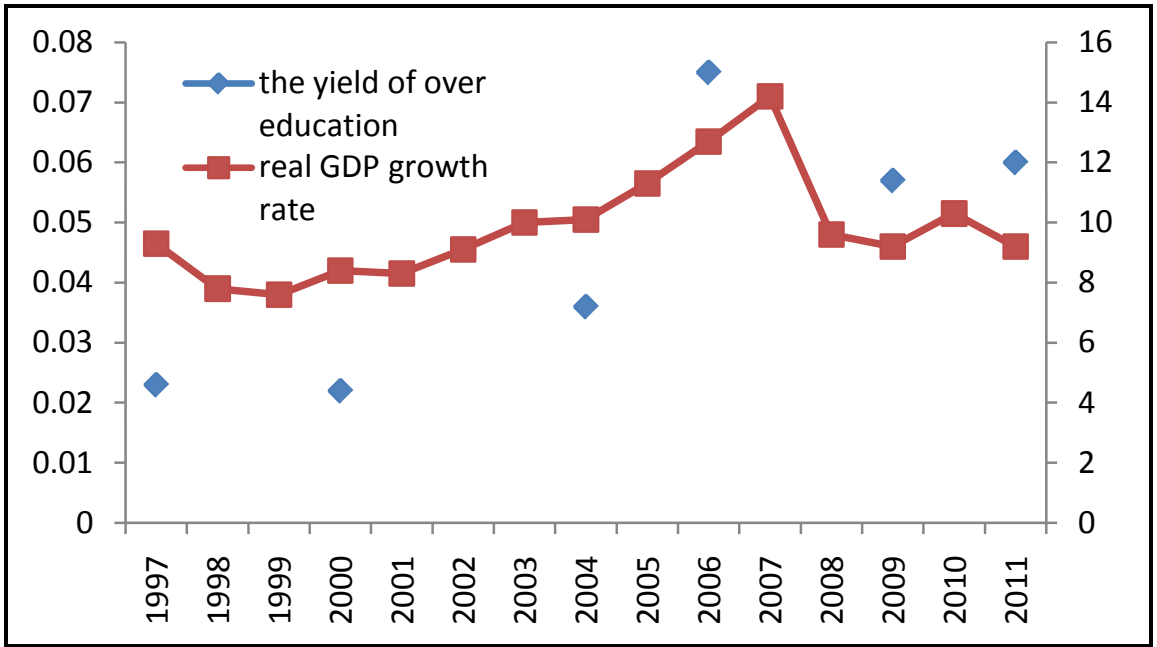

Figure 3. China's real GDP growth rate and the yield of overeducation in 1997-2011. Data source: "China Statistical Yearbook" and the results in Table 5. 
If there is inconsistency between education rising and economics dropping, the decreasing labors demand of the enterprises and the information lagging will lead to the stagnation of the labor market which may discourage the working force during recession period. The lagging may bring about more impact to the economics more than the education itself.

\section{Conclusions}

The analogous trend of overeducation yield and GDP development demonstrate that the economic development needs the support from education. For another part, additional income comes along with additional education years if the economics keeps developing. The room for wage premium illustrates that the human capital level in China is still approvable. And the overeducation yield is positive means lengthening the education years can also bring the income premium to the workers. All three phenomena indicate that education contributes considerably to Chinese development and more educational investment is needed for each human capital.

The high occurrence and income of overeducation human capital within the high-tech industry reveals the large demand of overeducation human capital from the high-tech industry. The industry structure of China is transforming from the predominant labor-intensive industry to technology intensive and capital intensive industry meaning that more and more educated skilled human labors are needed to support the transformation. More guidance for these high quality labors should be put forward to help them get into the suitable industry.

Meanwhile, with the increasing supply of overeducation workers, the income disparity of skilled and unskilled workers is gaining. Large amounts of peasant workers have dedicated themselves to Chinese previous economic booming. Considering the lessened demand for peasant workers accounting for the transformation period, government should encourage these unemployed peasant workers to engaged back in agriculture. On one hand, it can reinforce the food security of our country. On the other hand, it benefits the easing of the technological unemployment issues.

The income disparity between the workers with high education and low education is climbing, too. And the yield of appropriate education is lowered. Avoiding the crowding out effect and neglecting of the appropriate education group should also be highlighted.

\section{References}

[1] Carroll, D. and Tani, M. (2013) Over-Education of Recent Higher Education Graduates: New Australian Panel Evidence. Economics of Education Review, 32, $207-$ 218. https://doi.org/10.1016/j.econedurev.2012.10.002

[2] Lindley, J. (2009) The Over-Education of UK Immigrants and Minority Ethnic Groups: Evidence from the Labour Force Survey. Economics of Education Review, 28, 80-89. https://doi.org/10.1016/j.econedurev.2007.11.003

[3] Frenette, M. (2004) The Overqualified Canadian Graduate: The Role of the Academic Program in the Incidence, Persistence, and Economic Returns to Overquali- 
fication. Economics of Education Review, 23, 29-45. https://doi.org/10.1016/S0272-7757(03)00043-8

[4] Dearden, L. (1998) Ability, Families, Education and Earnings in Britain. Labour Economics, 6, 551-567. https://doi.org/10.1016/S0927-5371(98)00015-3

[5] Dearden, L and Sianesi, B. (2001) Estimating the Returns to Education: Models, Methods and Results. Barbara Sianesi, 51, 300-321.

[6] Lindley, J. and Mcintosh, S. (2008) A Panel Data Analysis of the Incidence and Impact of Over-Education. Journal of Christian Education \& Information Technology, 28, 289-300.

[7] Sheng, S.M. (2009) Influencing Factors Analysis of the Incidence and Yield on Over-Education and Education Shortage. Re Education Forum, 7, 82-87.

[8] Peng, M.M. and Luo, R.D. (2011) Mismatch on China's Education and Its Impact on Wage Income. Academic Journal, 11, 71-77.

[9] Zhang, X.B. and Qi, P. (2011) The Research of Excessive Education Based on National Comprehensive Social Survey Data Analysis. Education Development Research, 31-36.

[10] Miao, Y.H. (2013) Current Situation of Overeducation and Analyse Its Influence Factors in China. Statistical Research, 48-54.

[11] Belfield, C. (2010) Over-Education: What Influence Does the Workplace Have? Economics of Education Review, 29, 236-245. https://doi.org/10.1016/j.econedurev.2009.08.001

[12] Tsang, M.C. (1987) The Impact of Underutilization of Education on Productivity: A Case Study of the U.S. Bell Companies. Economics of Education Review, 6, 239-254. https://doi.org/10.1016/0272-7757(87)90003-3

[13] Rubb, S. (2003) Overeducation: A Short or Long Run Phenomenon for Individuals? Economics of Education Review, 22, 389-394. https://doi.org/10.1016/S0272-7757(02)00052-3

[14] Farooq, S. (2011) Mismatch between Education and Occupation: A Case Study of Pakistani Graduates. Pakistan Development Review, 50, 531-553.

[15] Groot, W. and Brink, H.M.V.D. (2000) Overeducation in the Labor Market: A MetaAnalysis. Economics of Education Review, 19, 149-158. https://doi.org/10.1016/S0272-7757(99)00057-6

[16] Carroll, D. and Tani, M. (2013) Over-Education of Recent Higher Education Graduates: New Australian Panel Evidence. Original Research Article. Economics of Education Review, 2, 207-218. https://doi.org/10.1016/j.econedurev.2012.10.002

[17] Lindley, J. (2009) The Over-Education of UK Immigrants and Minority Ethnic Groups: Evidence from the Labour Force Survey. Economics of Education Review, 2, 80-89. https://doi.org/10.1016/j.econedurev.2007.11.003

[18] Moro-Egido, A.I. and Budría, S. (2008) Education, Over-Education, and Wage Inequality: Evidence for Spain. Economics of Education Review, 6, 332-341.

[19] Verdugo, R. R. and Verdugo, N.T. (1989) The Impact of Surplus Schooling on Earnings. Journal of Human Resources, 24, 629-643. https://doi.org/10.2307/145998 
Submit or recommend next manuscript to SCIRP and we will provide best service for you:

Accepting pre-submission inquiries through Email, Facebook, LinkedIn, Twitter, etc. A wide selection of journals (inclusive of 9 subjects, more than 200 journals)

Providing 24-hour high-quality service

User-friendly online submission system

Fair and swift peer-review system

Efficient typesetting and proofreading procedure

Display of the result of downloads and visits, as well as the number of cited articles Maximum dissemination of your research work

Submit your manuscript at: http://papersubmission.scirp.org/

Or contact jss@scirp.org 